\title{
Development of A Template Lesson Plan Based on 5e Model Enhanced with Computer Supported Applications and Conceptual Change Texts*
}

\author{
Burcu Sezginsoy Şeker ${ }^{1}$, Aliye Erdem ${ }^{2}$ \\ ${ }^{1}$ Balıkesir University, Faculty of Necatibey Education, Department of Elemantary Education, Balıkesir, Turkey \\ ${ }^{2}$ Ankara University Faculty of Educational Sciences, Department of Elemantary Education, Ankara, Turkey \\ Correspondence: Assist. Prof. Dr. Burcu Sezginsoy Şeker, Balikesir University, Faculty of Necatibey Education, \\ Department of Elementary Education, Elementary Teacher Education, 10100, Alt1eylül, Balıkesir, Turkey.
}

Received: July 26, 2017

doi:10.11114/jets.v5i10.2553
Accepted: September 5, $2017 \quad$ Online Published: September 10, 2017

URL: https://doi.org/10.11114/jets.v5i10.2553

\begin{abstract}
Students learning a defined subject only perform by learning of thinking based on the concepts forming that subjects. Otherwise, students may move away from the scientific meaning of concepts and may fall into conceptual errors. Students' conceptual errors affect their following learning and cause them resist change. It is possible to prevent this resistance with conceptual change texts. This study aimed to correct present concepts of students by exchanging them with new concepts and rearranging their present knowledge structure using conceptual change texts. Conceptual change texts were introduced at the explanation step of a 5e model by assuming that a $5 \mathrm{e}$ model enhanced with texts would make learning meaningful and permanent. In other steps of the 5e model, audio-visual elements such as animations, colored pictures, and computer-supported applications were used to increase the permanency and accessibility of knowledge. The objective of this study is to develop a lesson plan and activities based on the 5e model that would be a template for the learning outcome: "He/she distinguishes natural and man-made elements that he/she sees in his/her environment", which occurs in "The Place We Live" unit in 4th grade social sciences curriculum and for learning outcomes of the concepts in the same unit. Photostory 3 software is among the computer-supported applications used in the preparation of activities. Conceptual errors related to the subject were determined by literature review and by considering the students' opinions before preparation of conceptual change texts.
\end{abstract}

Keywords: conceptual change texts, education of social sciences, computer supported applications

\section{Introduction}

\subsection{Concept}

The Constructivist approach starts off from the opinion that knowledge is just formed by individuals and the student is active in this formation process. One form of this approach applied in social sciences education isthe 5e model which was developed by Trowbridge and Bybee (1990). The 5e education model can be considered a learning cycle that consists of 5 stages - as is evident from its name. It includes students in the learning process at every stage; it encourages them to form their own concepts and to construct their knowledge. Teaching based on the 5e education develops their conceptual understanding by starting from their everyday lives; it enables studies to be conducted with the aim of learning a known concept in detail and elimination of conceptual errors (Bybee, Taylor, Gardner, Van Scotter, Carlson, Powell, Westbrook and Landes, 2006). The model consists of the stages of entry, exploration, explanation, deepening, and assessment. In more detail, these are providing the motivation related to the class and participation in the entry stage; trying to explore the subject and the concepts used by finding out the preliminary information in the exploration stage; enhancing the concepts mentioned in the study during the explanation stage, moving the conceptual knowledge into action by applying it in new situations in the deepening stage; and assessing all $\mathrm{p}$ stages of the study and what has been gained in this process in the assessment stage (Lederman, 2009; Trowbridge, Bybee \& Powell, 2004; Sunal and Haas, 2012).

\footnotetext{
*This study was presented at the symposium of $16^{\text {th }}$ International Primary Teacher Education (USOS 2017) on 08-11 May 2017.
} 
Conceptual education is the most important infrastructure for providing a successful education. Conceptual change texts, concept maps, mind maps, concept cartoons, among other tools,. can be used in social science lessons to eliminate conceptual errors. Concepts are groups of symbols, events, and objects that share common features and are defined by the same name. Concepts organize the structure of knowledge, protect knowledge from scattering and nonfunctionality, and ease and accelerate the communication between people (Martorella, 1986; Merrill, 1983). People learn, classify, and explore the relations between concepts and the words that name them beginning starting from their childhood. Conceptual learning is a key for other learning because it encounters learning as a phenomenon at the center of education because their features provide communication between people and form a basis for developing principles (Şimşek, 2006: 28; Doğanay 2003; Ülgen, 2006:109).

In conceptual education the type of the concept and the age group of the students is an important factor. To provide effective conceptual education, learning environments must be created in which the learners in the education process can use their senses, explore the similarities and differences between objects, form experiences convenient for comparison, and associate these concepts with their daily lives (Birbili, 2007:147). Because having the knowledge of the concepts that form the basic building stones of the individual's cognitive structure and are the basis for all thinking skills, it is important to conduct a meaningful and permanent education. It is the key of meaningful learning that students integrate the concepts they had learned previously with the knowledge and experiences they have met recently. Otherwise, if the concepts do not become meaningful, students would revert to memorization (Ausubel, 2000; Novak \& Cañas, 2008). Therefore, to carry out an effective and meaningful conceptual educational process, student-centered learning environments inwhich the student themselves structure the knowledge presented by the education process and in which they have opportunities for learning by doing-living are required.

\subsection{Correction of Concept Errors}

Conceptual learning is a process that is realized initially in the primary education levels, is used lifelong, and forms a basis for new learnings. Students learning a particular subject actualize only by learning and thinking based on concepts that form that subject. Otherwise, students may stray from the scientific meaning of the concepts and may fall into conceptual errors. Conceptual errors that students acquire affect their ensuing learning and cause them resist change. It is possible to prevent this resistance using conceptual change texts.

Conceptual change texts are one of the main methods that provide meaningful learning by forming conceptual changes in students and that are used in the elimination of conceptual errors (Wang and Andre, 1991; Chambers and Andre, 1997). Conceptual change aims to correct the concepts of students have at presentby replacing them with new concepts and to reorganize their present knowledge structure. In these texts, firstly it begins with a question to determine students'present conceptual errors, likely conceptual errors that students have about the subject which will be taught are specified, the fallacies in these concepts are shown by explanations and examples. Thus, the attempt is to produce a conceptual change in the student's thinking by enabling the student to notice the inadequacy or fallacy of his knowledge. New scientific knowledge about the subject is explained with examples, and finally, it is explored whether the concepts are comprehended or not by an assessment study (Maria and MacGinitie, 1987; Chambers and Andre, 1997). Additionally, it is important to place importance on visuality in conceptual change texts, to embody abstract concepts that students find hard to comprehend by enhancing them with pictures and cartoons. (Özkan vd., 2001).

A literature search shows that conceptual change texts are an effective way to eliminate students'misunderstanding. The effectiveness of conceptual change texts in creating conceptual change in students and encouraging meaningful learning is set forth in many studies (Wang and Andre, 1991; Hydn and others, 1994; Chambers and Andre, 1997; Mikkila 2001; Sungur and others, 2001). Hewson and Hewson (1983) used a conceptual change approach to determine conceptual change related to concepts of density, mass, and volume. Their study results showed that using education strategies that consider students' misunderstanding s leads to better acquisition of scientific concepts. Hynd and his associates (1994) suggested that conceptual change texts are effective in creating conceptual change and in encouraging meaningful learning related to Newton's law of motion. Wang and Andre (1991), and Chambers and Andre (1997) stated that when conceptual change texts are compared to traditional texts, concept of electricity is better comprehended with conceptual change texts. Mikkila (2001), Sungur and his associates (2001) showed the effectiveness of conceptual change texts in comprehension of photosynthesis and the human circulatory system.

Studies have been conducted that show students have conceptual errors generally in the fields of physics, chemistry, and biology. It is possible that more studies are required aimed at elimination of these conceptual errors that result from the abundant abstract concepts in these field and students lacking an association of these concepts with daily life, revealing concept errors in these disciplines. Social science is a discipline that can unify more than one discipline. Many published studies reveal errors attached to concepts in the field of social sciences. According to those studies; students have difficulty in comprehending many concepts, especially those related to geography, and that students have 
significant conceptual errors (Yazıcı and Samanc1, 2003; Henriques, 2002; Akbaş, 2002; Alım, 2008; Doğar and Başıüyük, 2005).

Despite all these studies, studies aimed at eliminating conceptual errors are an inadequate. Yet, elimination of conceptual errors also matters along with determination of those conceptual errors for learning to be meaningful. In the present study, we aim to eliminate conceptual errors in social sciences teaching with a template lesson plan based upon $5 \mathrm{e}$ model. In the explanation stage of the $5 \mathrm{e}$ model conceptual change texts were chosen by considering that the $5 \mathrm{e}$ model when enhanced with conceptual change texts would make learning meaningful and permanent. In the other stages of the 5e model, audio visual elements such as animation, colored pictures, and computer-supported applications were used to increase memorability and noticeability of knowledge. Digital stories that are among computer-supported applications are produced by means of the Photostory 3 program.

\subsection{The Digital Story}

Digital narration expresses the process of producing a short film, generally between 2-10 minutes in lentgth, by associating a text or an original story with multimedia elements such as pictures, video, music or narration of author by his/her own voice. A digital story can be identified as video presentations that are rich in terms of multimedia elements, produced at the end of narrating process. In the social sciences, subjects related to abstract concepts occupy an important place, and digital stories have an important role in developing abstract thinking. Composing a story, listening to a story, reading a story develop creative thinking, and the story provides permanent learning when unified with education. Morever, multimedia applications appeal to more than one sense organ and make learning permanent by stimulating the learner through multiple sense organs (Turgut and Kışla, 2015, Dupain and Maguire, 2005, Bromberg vd., 2013). In this context, it is assumed that use of digital stories in social sciences teaching will enable students to learn more permanently. It will increase their interest and motivation because of digital stories are an impressive and concrete teaching material that provide thae combination of students' inner worlds and the course subject.

It is assumed that the digitalization of stories which students had grown up listening to induces indirect experiences; these stories will still arouses their attention after they are grown upand may increase their interest and motivation. Students who start to conduct research, analyze amouts of materia, synthesize, use the laboratory for research, will tell their own stories and have creative skills that can improve their communication skills. While they construct their digital stories, they learn how to organize their ideas, ask questions, expand their ideas, and set up their stories. Students who find the opportunity to present digital stories they have constructed gain experience by criticizing the work they have done; this experience leads to the acquisition of social learning. Digital storytelling encourages students who can collaborate as a team for cooperation gain a sense of personal belonging and overcoming something.

the research conducted about the use of construction of digital story as a teaching tool confirms that it was an efficient tool, strategy, or method for the learning and teaching process of the " $z$ " generation the children growing up with the technologyit enables the students to express themselves and to improve their skills like problem solving, critical thinking, and literacy. It provides an opportunity for students to put forward realistic products, to organize their thoughts consistently, and to write about them in a creative manner. (Ballast, Stephens, \& Radcliffe, 2008; Frazel, 2010; Gakhar, \& Thompson, 2007; Malita, \& Martin, 2010; Ohler, 2013; Yang, \& Wu, 2012).

\subsection{Integration of Information and Communication Technologies}

Today, information changes swiftly, the ways to access information diversify, and it is most important that students use the information technologies effectively. The knowledge and skills necessitated by the present time demand the alteration of the traditional educational status and its transformation parallel to technology. Students' following-up the developments in technological tools such as computer, internet, cell phone. Using these tools with the purpose of learning necessitates the development of new approaches in learning-teaching systems, and necessitates lesson plans and lesson materials to become interactive (Prensky 2001). Prensky has the opinion that today's students are quite different from the students whom our education system was designed to educate. Teachers who are described as digital immigrants are required to improve their technical skills to be effective for teaching digital native students. They need to move toward education models and equipment that today's digital native students may use enthusiastically and actively by dispensing with classical education models. Otherwise, it would be difficult to engage the attention of digital natives whose perception and life styles have changed. This situation shall be possible through enabling integration of information and communication technologies into learning and teaching processes. Technology integration in education is a complex and multidimensional process in which various variables in administrative, educational and institutional sense are considered apart from today's technologies (Yurdakul\&Kabakçi 2011). Effective integration of technology to the learning-teaching process does not emphasize learning from technology, but learning with technology (Tezci, 2016). To provide this, integrating learning strategies with technology in learning-teaching process, forming lesson plans on this basis and enhancement of these lesson plans using so many different technologies "software, interactive 
applications, social network platforms, web 2.0 technologies...", in short, the learning-teaching environment must be designed together with technology. Searches of published studies show that ITC provides an approach from its teaching as a subject field separate from its integration into education programs, and ITC's integration into learning-teaching process increases gradually (Cartwright and Hammond, 2003; Compton and Harwood, 2003; Gough, 2000; Herzig, 2004; Melle and others, 2003). Effective integration of ITC into the learning-teaching process is not an event that occurs only by the design of the program. Teachers, the essential implementers using these designs are also very important. In this study, the lesson plan and activies were prepared based on information and communication technologies and were published as a sample for the teachers who are the essential implementers.

The objective of the present study is to develop a lesson plan and activities according to the 5e model which would be an template for learning outcome of "He/she distinguishes natural and human-made elements which he/she sees in his/her environment"; this takes place in "The Place We Live" unit in 4th grade Social Sciences Lesson Cirriculum and for learning outcome of the concepts in the same unit. The digital story was constructed using Photostory 3 software, one of the computer-supported applications used to prepare activities. Concept errors related to the subject were determined by review of the literature and by inviting the opinions of students before preparing conceptual change texts.

\section{Method}

This study preoceeds in four different stages. In the first stage interviews were held with teachers and subjects to determine which students may have concept errors, with the literature support and expert opinions it was decided that the subject shall be "natural - human-made elements", which takes place in the social sciences lesson of 4. grade. The second stage is the most comprehensive stage of the study because at this point the attempt was to discover which conceptual errors students have related to that subject. Therefore, the interview form was prepared and filled in by students. In the fall semester of 2016-2017, opinions of 55 students who study at 4A (30 students) and 4D (25 students) classes of Balıkesir Altı Eylül and Balıkesir Namık Kemal Primary School were collected. The case study method adopted in the second stage of the study is among the qualitative research patterns. Case studies present rich, deep, and explanatory information about the objective of the study. In this type of study, people, subjects, problems, and programs can be examined closely (Hays, 2004). In this study, 55 students constituted the study group. Convenience sampling, a purposive sampling method, was chosen. In this method the researcher chooses a case that is close and convenient (Şimşek ve Yıldırım). At the third stage of the study, conceptual change texts based upon the concept errors determined in the second stage were developed by computer-supported applications. At the last stage of the study, published lesson plans according to 5e model, were examined, and a lesson plan sample was developed by supporting the entry, exploring, explanation, deepening, and assessment stages seperately with computer-supported visuals and conceptual change texts were prepared. In the developing process of the data-collecting tool, all these stages are clarified with details.

\subsection{Development of Data Collection Tool}

In this research, the primary concept errors with regard to the concepts mentioned within the learning outcome of "He/she distinguishes natural and human-made elements which he/she sees in his/her environment" were ascertained, then conceptual change texts based upon these errors were developed. Computer-supported materials, conceptual change texts, and application stages of $5 \mathrm{e}$ model are listed below:

1. At the end of the teacher interviews, including the teaching experience of the researcher and the literature search, it was determined that one of the subjects that causes students difficulty was "natural-human-made elements".

2. The opinions of the students related to the concepts of natural and human elements were received by a semi-structured interview form. For the content validity of the interview form, the opinions were asked of the instructors employed in the departments of primary school teaching and educational sciences. Items in the interview form were organized with the direction of expert opinions and based on the purpose of the study. In this context, four interview questions were determined. These questions were about what natural element concept and artificial element concept are, with examples relevant to them. Answer to the interview form were analyzed by describing in-depth (by using content analysis) and converted into suitable themes. Similar expressions as answers to questions were listed and their usage frequency were determined. Then the deducted codes were accumulated under common titles. At the beginning, coding was done seperately, then consistency rates were calculated, which showed that researchers came to an agreement at the rate of $90 \%$. It can be stated that consistency between the categories determined by the researchers was observed.

3. At Table 1, opinions of students related to the concepts of natural and human-made elements took place. A conspicuous aspect of this table is that it shows existing concept errors of students. For example, about the "Natural element" concept, $10.9 \%$ of 55 students expressed this concept as "Natural numbers". In the conceptual change text prepared within this context, the elimination of this error was attempted. $12.72 \%$ of the students identify "natural element" as "human-made elements". 
4. Another conspicuous category at Table 1 is expressions given as the examples of natural element. Students expressed a total of 70 opinions about this subject. "Trees" is the most given example to the natural element concept, with an average of $21 \%$. Students who had a concept error expressed the categories of desk, table, pencil, notebook, park, and landslide as examples to natural elements. In the conceptual change texts, the errors of students related to these concepts are approached. In the conceptual change texts; it was explained with computer-supported visuals and activities that the raw materials of desk, table, pencil and notebook are natural, but their final form is manmade; that landslide is a natural "phenomenon" not a natural "element", and there are natural and artificial elements together within the concept of park.

5. When Table 1 is examined further, it can be said that the man-made element concept is understood correctly. But the examples of the man-made element show that students' knowledge is incorrect. The categories of "tree" and "park", which were given as example of "hman-made element", indicate that misunderstanding. $6.73 \%$ of students stated that human beings dibbled saplings to soil and it grow up by intervention of human-being, so "tree" concept was an artificial element. This error is specified in conceptual change texts with the explanation that human being does not create sapling, seeds of saplings are created in nature by itself.

Table 1. Students' opinions about the concepts of "Natural and human-made elements"

\begin{tabular}{|c|c|c|c|}
\hline \multirow{3}{*}{$\begin{array}{l}\text { Questions } \\
\text { 1.What does the "Natural } \\
\text { Element" } \\
\text { concept mean to you? }\end{array}$} & \multirow{2}{*}{\begin{tabular}{|l} 
Categories \\
Natural Numbers
\end{tabular}} & \multicolumn{2}{|c|}{ FrequencyPercent } \\
\hline & & 6 & 10.9 \\
\hline & $\begin{array}{l}\text { Things that exist and spring by itself } \\
\text { in nature }\end{array}$ & 5 & 9.09 \\
\hline & The nature itself & 6 & 10.9 \\
\hline & Artificial elements & 7 & 12.72 \\
\hline & Things that were not produced by hume & & 14.54 \\
\hline & Things in our life & 7 & 12.72 \\
\hline & Things that are formed by themselves & 10 & 18.18 \\
\hline & No answer & 6 & 10.9 \\
\hline & Total & 55 & 100 \\
\hline \multicolumn{4}{|l|}{ 2. Examples of } \\
\hline \multirow{13}{*}{ Natural Element } & Forest & 7 & 10 \\
\hline & Sea & 5 & 7.14 \\
\hline & River & 6 & 8.57 \\
\hline & Flower & 10 & 14.28 \\
\hline & Park & 4 & 5.71 \\
\hline & Land slide & 3 & 4.28 \\
\hline & Desk & 3 & 4.28 \\
\hline & Table & 3 & 4.28 \\
\hline & $\overline{\text { Pencil }}$ & 3 & 4.28 \\
\hline & Notebook & 2 & 4.28 \\
\hline & Fruit & 4 & 5.71 \\
\hline & Sun & 5 & 7.14 \\
\hline & Total & 70 & 100 \\
\hline \multicolumn{2}{|c|}{ 3.What does a "Man-madeArticial things } & 19 & 34.54 \\
\hline \multirow[t]{4}{*}{ Element" mean } & Things that are not formed by themselv & 14 & 25.45 \\
\hline & Things that are made by human & 17 & 30.90 \\
\hline & No answer & 5 & 9.09 \\
\hline & Total & 55 & 100 \\
\hline 4. Examples of & Tree & 7 & 6.73 \\
\hline \multirow[t]{9}{*}{ A Man-made Element } & Television & 10 & 9.61 \\
\hline & Buildings & 9 & 8.65 \\
\hline & House & 22 & 21.15 \\
\hline & Car & 18 & 17.30 \\
\hline & Park & 6 & 5.76 \\
\hline & Telephone & 12 & 11.53 \\
\hline & Tablet & 7 & 6.73 \\
\hline & Computer & 13 & 12.5 \\
\hline & Total & 104 & 100 \\
\hline
\end{tabular}


6. In the process of preparing conceptual change texts; computer-supported visuals and texts were chosen by reference to the concept errors determined above (see Table 1).

7. The lesson plan according to the 5e model, which would be a template for the learning outcome of "He/she distinguishes natural and human-made elements that he/she sees in his/her environment", which occurs in "The Place We Live" unit in 4. grade Social Sciences Lesson Curriculum and for learning the outcome of the concepts in the same unit was planned using the resources "Social studies for the preschool/primary child" (Seefeldt, Castle and Falconer, 2015), and "The BSCS 5E Instructional Model: Creating Teachable Moments" (Bybee and others, 2006).

8. In the "entry" stage of the prepared lesson plan, the activity "What are there in my environment" was conducted with students to help them remember what they know about the subject; they were asked to make a drawing that describes what they see in their environments using Play Doh.

9. In the "exploring" stage of the $5 \mathrm{e}$ model, students generate ideas to try to solve a problem by cooperating, doing experiments, studying in a computer, video, or library environment as the teacher chooses. Thus, in the lesson plan, a digital story scenario was prepared, drawings related to the scenario were produced, using Photostory 3 software to vocalization and effects to the pictures.

10. In the "explanation" step of the lesson plan; the teacher helps students to replace their inadequate previous notions with the new ones that are more promising for learning; conceptual change texts were used. Then natural and human-made elements were classified by the figures formed by the Play-Doh.

11. In the "deepening" step, because this step requires that knowledge realized and experiences acquired in the earlier stages should be used correctly, this learning should be associated with if possible with different disciplines. Natural and man-made elements in the digital story were expressed on a column chart, and subsequently, the "Labyrinth" game was designed.

12. In the "assessment" step of lesson plan, the "diagnostic tree" scale technique was used.

\section{Results}

In this chapter; a lesson plan and activities were devised based on the 5e model as a template for the learning outcome of "He/she distinguishes natural and human-made elements which he/she sees in his/her environment", which occurs in "The Place We Live" unit. For the learning outcome, the concepts in the same unit were presented. The lesson plan as prepared and activities are as follows:

Lesson Plan-Chapter 1

Name of the Lesson: Social Sciences

Grade: 4. Grade

Name of the Unit: The Place We Live

Subject: Natural and Human-made Elements in our Environment

Suggested Time: $40+40$ minutes

Lesson Plan-Chapter 2

Explanations Related to the Application of the Plan

Entry Step:

Teacher enters the classroom and greets the students. "What aisre there in my environment?" activity is conducted with students. An environmental excursion around the school is organized and students take paper and a pencil with them. They are asked to list everything they see during the excursion. Students are reminded that the things they have listed are both natural and man-made elements. Afterward the excursion these questions are asked:"What did you see around the school? Can you make the drawing of one thing you saw with Play Doh?" After the students make the drawings of what they have seen in their environment, the teacher asks: "Why don't we see waterfalls when we arrive by the road? Why don't we see a forest? Why do we always see buildings?" The answers to the questions are recorded; the answer being correct or wrong is not important. The aim is to direct students to the subject and encourage them to inquire in their minds.

\section{Exploring Step:}

The student asks: "Shall we all watch a video now?" "The digital story" (with examples from its pictures below) is watched to students. After the video, the teacher asks: "In the video we jut watched, where did Tahir Efe go and what did he see? Can you list these?" Students make their lists and share them with the class. Then the teacher says: "Now let 
us make two groups from what you have written to this list". The students go into their groups. The teacher asks: "How have you classified the things you had wrote in the groups you put together? What would be their names, if you had to name these groups?" Thus, the teacher takes the first step in revealing the existing conceptutal errors of students.

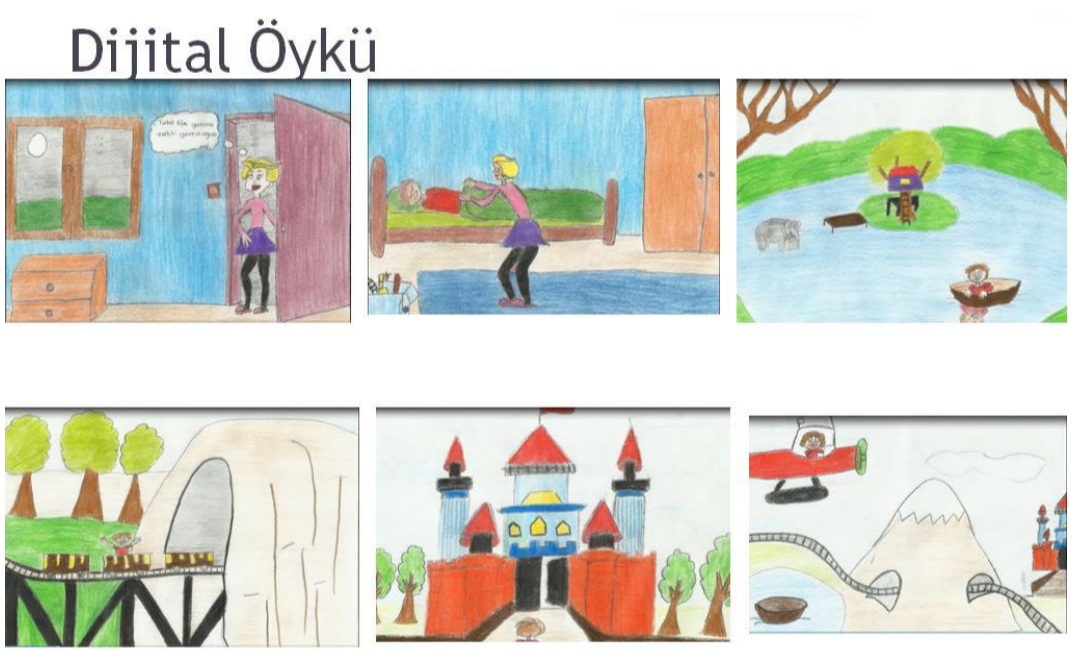

\section{Explanation Step:}

The teacher asks; "What do natural and man-made mean for you?" After the answers are recorded teacher explains the concepts scientifically by referring to the conceptual errors text. The conceptual change text below is examined with the students. The conceptual errors of students are examined and corrected using the conceptual change texts, as in the example given below. Then the knowledge of the students about the subject is determined with the assessment study.

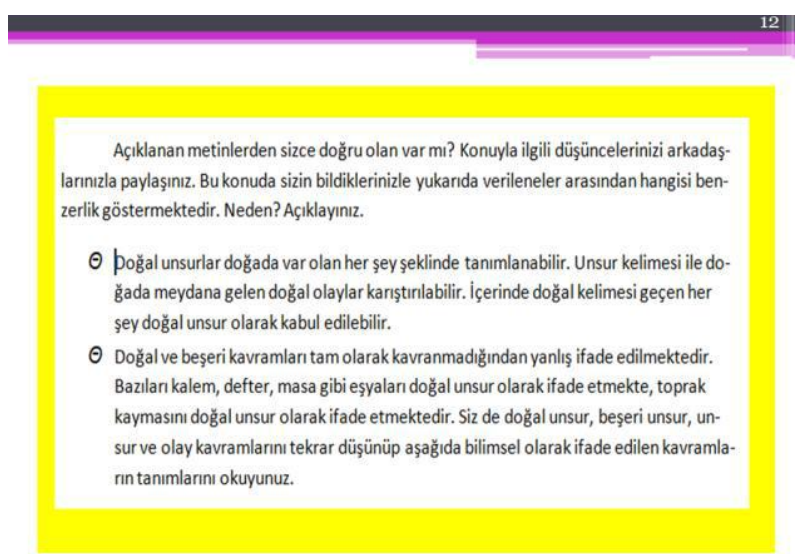

The teacher says: "Children, now it is time to take out the Play Doh figures that you have put aside under your desks". Students take out the figures from under their desks. The teacher says: "Now, I want you to attach these things you have done to correct places on the cardboard of natural and hand-made elements. The students then attach their figures to places on the cardboard of natural and man-made elements. The teacher questions them about why they have attached certain figures to the natura lor man-made areas, and the students explain their reasons. They benefit from feedback and correction; this directs students to understand what is uncorrect in their errors.

\section{Cardboards of Natural Element-Human-made Element}
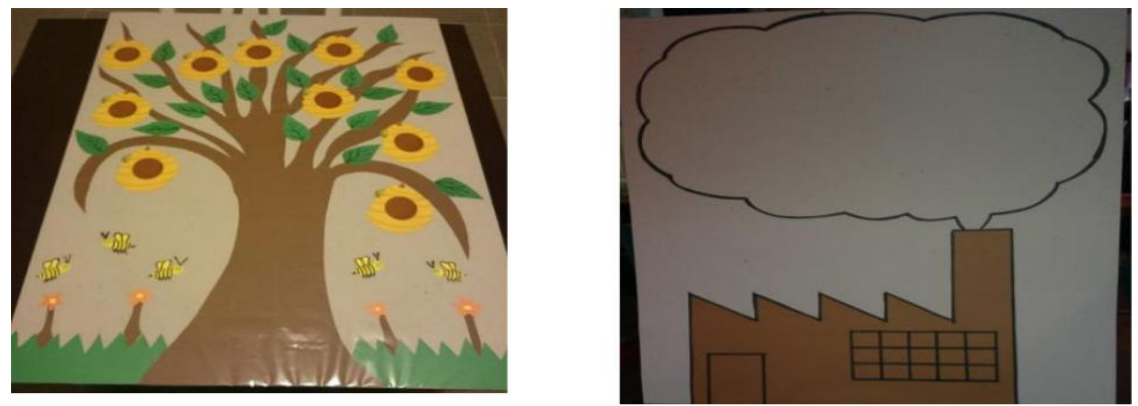


\section{Deepening Step:}

The teacher says; "We will watch our digital video again. I want you to check the natural and man-made elements and reorganize them while you are watching the story." After video is finished, the students are asked to show their lists. One student is chosen and asked how many natural and how many man-made elements he/she discovered. Then the teacher asks students to express these in a column chart. One student comes to the blackboard and expresses his/her data on a column chart. After the student has drawn the column chart, the teacher asks "What can we conclude from this graph?" The teacher expects the comment that man-made elements are more common than natural elements. Subsequently, the "Labyrinth" game is played:

Name of the Game: Labyrinth

1. Period of the Game: $15-20$ minutes

2. Objective of the Game: Person relaxes, socializes, and performs his mental activities at a high level while playing. The aim: the targeted learning outcome should be acquired by students in an entertaining manner and should become a permanent behavioral change.

\section{The Unit of the Game: The Place We Live}

4. The Relation of the Game with the Learning Outcome: He/she distinguishes natural and man-made elements in his/her environment.

5. The Relation of the Game with Grade: 4-5. grade

6. Game Equipment :

- Question Envelopes

- Picture cards of natural and man-made beauties in Turkey

- Game Envelopes

- Board marker

- $\quad$ Game base

- Number of players: 4-32

7. Application Steps of the Game:

- While starting the game:

The class is divided into groups of four. Everyone plays one turn individually. Every individual touches another friend after playing and the game continues this way. One point is given for every correct answer and one point is subtracted for every wrong answer. In addition, whoever gets out of the labyrinth first takes 4 points, the second gets 3 points, the third gets 2 points, and the fourth gets one point. Eventually, whoever gets the most points wins the game.

\section{- How to Play?}

The mathematical operation on the first envelope is completed and the answers are shown to the teacher. After it is agreed that the answer is correct, the envelope is opened; it is decided whether the pictures inside it are natural or man-made elements, and that is written on the envelope. The player touches another friend and the turn passes to that student. Student takes a step further with pin and do the same things with the second envelope. The game proceeds like this. At last one point is given for every correct answer and one point is subtracted for every wrong answer. Whoever gets out from the labyrinth first gets 4 points, the second gets 3 points, the third gets 2 points and the fourth gets one point. Eventually, whoever gets the most points wins the game.

\section{Assessment Step:}

A prepared diagnostic tree scale is assigned to the students. Time allowed for the students for answers os announced. The questions are answered after all students have finished. The teacher assesses the process with the diagnostic tree scale below. 


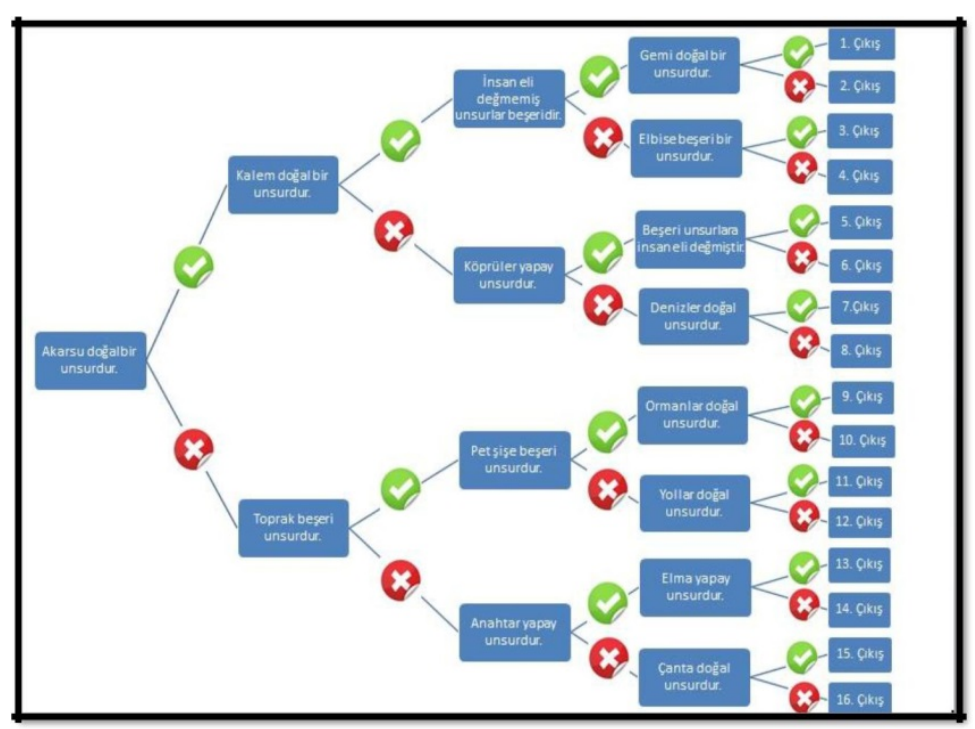

\section{Discussion}

It is possible that abstract subjects and concepts in social sciences lesson lead students to have conceptual errors about subjects and have negative attitudes toward this topic (Akbaş \& Toros 2016, Alkış, 2005, 2006; Aybek, 2001; Özcan, 2010; Doğar \& Başı̈̈̈yük, (2005). The suggested reasons for this are: difficulty of structuring abstract concepts in the mind without having concrete experience; these concepts take place in teaching environment without being associated with daily life; teaching by using one strategy without integrating different teaching strategies; conducting the teaching process focused on knowledge components and not organized around the concepts that should be acquired. Meanwhile, using methods and techniques that make teaching of the subjects in social sciences lesson more fun and invigorating for the students will increase the memorability of concepts. The objective of this study is to develop a lesson plan and activities according to the 5e model as a template for learning the outcome of "He/she distinguishes natural and man-made elements that he/she sees in his/her environment"; this is part of the "The Place We Live" unit in the 4. grade Social Sciences Lesson Cirriculum and for a learning outcome of the concepts in the same unit.

In published studies, many researchers have conducted their research aimed at developing lesson plans and activities using different methods. Ören and Yılmaz (2013) developed a guide material supported with scientific stories and concept cartoons for the "humans and environment" unit of 7. grade science and technology lesson. Aydın and Balım (2013) prepared lesson plans and activities based on conceptual change strategies based on the 5e model for the "cellular division and heredity" subject of the 8. grade science and technology lesson. Haşlaman, Mumcu and Usluel (2007) researched the integration of knowledge and communication technologies with learning-teaching process in new educational programs and prepared lesson plan templates integrated with information technology (IT). Saka and Akdeniz (2006) developed computer-supported education materials prepared in "Flash" software which consists of animation and simulations about chromosome-DNA-gene concepts, genetic crosswise and cloning subjects that teacher candidates have difficulty in comprehending, and thenused these materials within activities prepared based on the $5 \mathrm{e}$ model. Şahin and Yağbasan (2012) called attention to the abundance of abstract concepts in physics education and developed lesson plan templates in which creative drama is used as a method for physics education. Şahin, Akbulut and Çepni (2012) developed guide materials consisting of animation, analogy, and study leaflets based on the 5e education model for teaching "solid pressure" to 8. grade students.

When published studies are analyzed, the literatüre shows that there are many studies in various subjects that develop concept cartoons based on the 5e model or integrate computer and communication technologies with 5thee model. However, there are no guide for lesson plans and activities the enhance the 5e model with concept cartoons-computer supported applications and conceptual change texts. This shows that prepared lesson plans and activities would be a guide to teachers. Until these plans are published, when a sample lesson plan is applied, it would also develop the IT skills of the students. Analysis of published studies shows that digital stories are effective in developing students' IT skills (Sadik, 2008; Ohler, 2013; Robin, 2006; Barrett 2006; Thang \& Mahmud, 2017; Smeda et al., 2014). In addition, the European Union (EU) approves the notion that a fundemental transformation is necessary in education for member states to access the new information, skills, and a broader range of the qualifications required in the information age. Education partners in the EU level acknowledge the contribution of information and communication technologies (ICT) in reaching determined educational targets and emphasize that ICTs support and improve learning and creativity (Papadakis, , 2016). In Turkey, which is a candidate for membership in the European Union, studies related to the 
integration of ICTs to education proceeds swiftly. Especially in Turkey, the FATIH (Movement of Increasing the Opportunities and Enhancing Technology) project that is conducted by Ministry of Education and brings technological expansion to education is the biggest indicator of this change in education. The EBA (Education Informatics Network), which is one of the largest parts of the Project, is based upon producing electronical materials and content using the 5e model and the integration of computer communication technologies to education. Lesson plans and e-materials that are prepared within this scope serve as a model to the EBA for lesson content as part of the project. However, the development of a lesson plan template specific to social sciences is at the focus of the present study. Fort hat reason, the preparation process of the lesson plan is provided in detail to inspire educators in other fields. In addition, conceptual change texts prepared for the topic "natural and man-made elements" would be effective in eliminating incorrect definitions that students have about for concepts. With the present study, the educational content supported with a digital story that may benefit teachers comes into the educational techniques literature. As another consequence of the study, activities based upon the 5e model will further academical success, motivation, and attitudes belonging to social sciences lessons that take a positive approach to abstract concepts. Some recommendations are developed on the basis of this study. Ways of eliminating concept errors by means of conceptual change texts can be performed for different units and grades in the social sciences and the results can be compared. Digital narrating studies, which can be a lesson tool for teachers and students, may be implemented for different lessons; thereby the use of technology in the education may be generalized. While today's students who are seen as the digital generation and their teachers prepare creative education materials by themselves with this method, the permanence of learning can also be provided. On the basis of this study, educators can make various amendments on the lesson plan prepared according to the 5e model by considering the special needs of their own students, or they can form new lesson plans by starting from this lesson plan.

\section{References}

Akbaş, Y. (2002). Secondary 6th grade students understanding level of geographical concepts and their misconceptions. Unpublished master's thesis,Karadeniz Technical University Institute of Social Sciences, Trabzon.

Akbaş, Y., \& Toros, S. (2016). The Effects of Using Interactive Cartoons and Concept Maps on Academic Achievement in Social Studies Teaching, TURKISH STUDIES -International Periodical for the Languages, Literature and History of Turkish or Turkic, 11/9 Spring 2016, 53-68. https://doi.org/10.7827/TurkishStudies.9727

Alım, M. (2008). Levels of Understanding and Concepts Misconceptions of Students' Concepts in Place Circle and Map Information Units with High School Geography Program. Journal of Milli Eğitim, 177, 166-180.

Alkış, S. (2005). Determination of concepts related to geography subjects in primary school social studies textbooks, Marmara Geographical Review, 11(1), 83-92.

Alkış, S. (2006) Primary School Students' Conceptions of Precipitation. Elemantary Education Online, 5(2), 126-140.

Ausubel, D. P. (2000). The acquisition and retention of knowledge: a cognitive view, Boston: Kluwer. https://doi.org/10.1007/978-94-015-9454-7

Aybek, B. (2001). An analysis of the relationship between fourth grade social studies instruction with social sciences and other science branches. Journal of Çukurova University Institute of Social Sciences, 7(7), 34-48.

Aydın, G., \& Balım, A. G. (2013). Science and Technology Course Plans and Activities Based on Conceptual Change Strategies. Journal of Research in Education and Teaching, 2(1), 327-337.

Ballast, K., Stephens, L., \& Radcliffe, R. (2008). The Effects of Digital Storytelling on Sixth Grade Students' Writing and Their Attitudes about Writing. In K. McFerrin, R. Weber, R. Carlsen \& D. Willis (Eds.), Proceedings of Society for Information Technology \& Teacher Education International Conference (pp. 875-879). Chesapeake, VA: Association for the Advancement of Computing in Education (AACE).

Barrett, H. C. (2006). "Researching and Evaluating Digital Storytelling as a Deep Learning Tool". Proceedings of the 2006 Society for Information Technology and Teacher Education Conference. [Internet document available at http://electronicportfolios.org/portfolios/SITEStorytelling2006.pdf]

Birbili, M. (2007). Making the Case for a Conceptually Based Curriculum in Early Childhood Education. Early Childhood Journal, 35(2), 141-147. https://doi.org/10.1007/s10643-006-0112-0

Bromberg, N. R., Techatassanasoontorn, A. A., \& Andrade, A. D. (2013). Engaging Students: Digital Storytelling in Information Systems Learning. Pasific Asia Journal of the Association for Information Systems, 5(1), 1-22.

Bybee, R. W., Taylor, J. A., Gardner, A., Van Scotter, P., Carlson Powell, J., Westbrook, A., \& Landes, N. (2006). The BSCS 5E Instructional Model: Origins, Effectiveness and Applications. (p.1-65) Web:www.bscs.org/bscs-5Einstructional-model adresinden 18 Mart2016’te alınmıştır 
Cartwright, V., \& Hammond, M. (2003). The integration and embedding of ICT into the school curriculum: more questions than answers. In ITTE 2003 Annual Conference of the Association of Information Technology for Teacher Education, Trinity and All Saints College, Leeds.

Chambers, S. K., \& Andre, T. (1997). Gender, prior knowledge, interest, and experience in electricity and conceptual change text manipulations in learning about direct current. Journal of Research in science Teaching, 34(2), 107-123. https://doi.org/10.1002/(SICI)1098-2736(199702)34:2<107::AID-TEA2>3.0.CO;2-X

Compton, V., \& Harwood, C. (2003). Enhancing technological practice: An assessment framework for technology education in New Zealand. International Journal of Technology and Design Education, 13(1), 1-26. https://doi.org/10.1023/B:ITDE.0000039567.67842.c3

Doğanay, A. (2004). Development of concepts and generalizations in teaching. C. Öztürk- D. Dilek (Eds.), Life science and social studies teaching (pp. 226-256), Ankara: PegemA Press.

Doğar, Ç., \& Başıüyük, A. (2005) The understanding levels on weather and climate concepts for primary and secondary students. Kastamonu Education Journal, 29, 347.

Dupain, M., \& Maguire, L. (2005). Digital story book projects 101: How to create and implement digital storytelling into your curriculum. In $21^{\text {st }}$ Annual Conference on Distance Teaching and Learning. (pp.1-4).

Frazel, M. (2010). Digital storytelling guide for educators. Washington, DC: International Society for Technology in Education.

Gakhar, S., \& Thompson, A. (2007). Digital storytelling: Engaging, communicating, and collaborating. In Society for Information Technology \& Teacher Education International Conference, 2007(1), 607-612.

Gough, J. (2000). Critique: the impact of ICT on school education-a case study. In Contemporary approaches to research in mathematics, science, health and environmental education 2000: conference and symposium proceedings 6, January (pp. 127-135).

Haşlaman, T., Mumcu, F. K., \& Usluel, Y. K. (2010). The Integration of Information and Communication Technologies in Learning and Teaching Process: A Lesson Plan Example. Education and Science, 32(146), 54-63.

Hays P. A. (2004). Case study research. In K. deMarrais \& S. D. Lapan (Eds.) Foundations for research: Methods of inquiry in education and the social sciences (pp. 218-234). LEA Publishing.

Henriques, L. (2002). Children's ideas about weather: A review of the literature. School Science and Mathematics, 102(5), 202-215. https://doi.org/10.1111/j.1949-8594.2002.tb18143.x

Hynd, C. R., McWhorter, J. Y., Phares, V. L., \& Suttles, C. W. (1994). The role of instruction in conceptual change in high school physics topics. Journal of Research in Science Teaching, 31, 933-946. https://doi.org/10.1002/tea.3660310908

Lederman, J. S. (2009). Levels of Inquiry and the 5 E's Learning Cycle Model. Monterey, CA: National Geographic School Publishing Web:

http://www.ngspscience.com/profdev/Monographs/SCL22-0407A_SCI_AM_Lederman_lores.pdfadresinden28Nis an 2016'te alınmıştır

Malita, L., \& Martin, C. (2010). Digital storytelling as web passport to success in the 21 st century. Procedia-Social and Behavioral Sciences, 2(2), 3060-3064. https://doi.org/10.1016/j.sbspro.2010.03.465

Maria, K., \& MacGinitie, W. (1987). Learning from texts that refute the reader's prior knowledge. Literacy Research and Instruction, 26(4), 222-238. https://doi.org/10.1080/19388078709557912

Martorella, P. H. (1986). Teaching Concepts. In J. M. Cooper (Eds.), Classroom teaching skills. Copyright D.C. Healt and Company.

Merrill, M. D. (1983). Component display theory. In C. M. Reigeluth (Eds.), Instructional design theories and models (pp. 279-330). Hillsdale, NJ: Lawrence Erlbaum.

Mikkilä, M. (2001). Improving Conceptual Change Concerning Photosynthesis Through Text Design, Learning and Instruction, 11, 241-257. https://doi.org/10.1016/S0959-4752(00)00041-4

Novak, J. D., \& Canas, A. J. (2008). The Theory Underlying Concept Maps and How to Construct and Use Them. Technical Report IHMC CmapTools 2006-01, Florida: Institute for Human and Machine Cognition. Retrieved from, http://cmap.ihmc.us/Publications/ResearchPapers/TheoryUnderlyingConceptMaps.pdf

Ohler, J. B. (2013). Digital storytelling in the classroom: New media pathways to literacy, learning, and creativity. Corwin Press. https://doi.org/10.4135/9781452277479 
Özcan, N. (2010). The level of learning the concepts in the unit "Step by Step Turkey" in social sciences lesson at 5th grade primary education, (Unbuplished master thessis). Ankara: Faculty of Education University of Gazi in Ankara.

Özkan, Ö., Tekkaya, C., \& Geban, Ö. (2001). Remediation of misconceptions related to ecological concepts through conceptual change texts. Symposium on Science Education in Turkey at the Beginning of the New Millennium, September, İstanbul, Proceedings Book: 191-193.

Papadakis, S. (2016). Creativity and innovation in European education. Ten years eTwinning. Past, present and the future. International Journal of Technology Enhanced Learning, 8(3-4), 279-296. https://doi.org/10.1504/IJTEL.2016.082315

Prensky, M. (2001). Digital natives, digital immigrants part 1. On the horizon,9(5), 1-6. https://doi.org/10.1108/10748120110424816

Robin, B. R. (2006) "The Educational Uses of Digital Storytelling". [Internet document available at http://www.coe.uh.edu/digital-storytelling/evaluation.htm]

Sadik, A. (2008). Digital storytelling: A meaningful technology-integrated approach for engaged student learning. Educational technology research and development, 56(4), 487-506. https://doi.org/10.1007/s11423-008-9091-8

Saka, A., \& Akdenız, A. R. (2006). The development of computer based material about genetic and application according to 5e model.Turkish Online Journal of Educational Technology, 5(1).

Seefeldt, C., Castle, S., \& Falconer, R. C. (2015). Social studies for the preschool/primary child. Sevgi Çoskun-Keskin (Eds.) Ankara: Nobel Publication.

Smeda, N., Dakich, E., \& Sharda, N. (2014). The effectiveness of digital storytelling in the classrooms: A comprehensive study. Smart Learning Environments, 1(6), 1-21. https://doi.org/10.1186/s40561-014-0006-3

Sunal, C. S., \& Haas, M. E. (2012). Social Studies for Elementary and Middle Grades A Constructivist Approach. (4th Edition). Pearson Education

Sungur, S., Tekkaya C., \& Geban Ö. (2001). Contribution of Conceptual Change Texts Accompanied by Concept Mapping to Students' Understanding of the Human Circulatory System, School Science and Mathematics, 101(2), 91-101. https://doi.org/10.1111/j.1949-8594.2001.tb18010.x

Şahin, Ç., Akbulut, H. İ., \& Çepni, S. (2012). Teaching of solid pressure with animation, analogy and worksheet to primary 8th students. Journal of Instructional Technologies \& Teacher Education, 1(1), 22-51.

Şahin, E., \& Yağbasan, R. (2012). Creatıve drama in physıcs educatıon and a sample lesson plan: the event of tide. Journal of Buca Education Faculty, 34, 79-98.

Şaşmaz-Ören, F., \& Y1lmaz, T. (2013) Developing guide material study based on scientific stories by supported concept cartoons in the science and technology course. Journal of Research in Education and Teaching, 2(2), 130-141.

Şimşek, A. (2006). Content Based Instruction, A. Şimşek (Eds.), Teaching Concepts, (27-70). Ankara: Nobel Publishing.

Tezci, E. (2016). Developing A Scale For Measuring ICT Integration Approaches for Teachers. Kastamonu Education Journal, 24(2).

Thang, S. M., \& Mahmud, N. (2017). Digital Storytelling and Its Contributions to Development of Workplace Skills in a Southeast-Asian Context. Nirwan Idrus, 15(1), 20.

Trowbridge, L., Bybee, R., \& Powell, J. (2004). Teaching secondary school science: strategies for developing scientific literacy. Upper Saddle River, NJ: Merrill/

Trowbridge, L., W., \& Bybee, R. (1990). Becoming a Secondary Scholl Science Teacher. Columbus Ohio USA Merrill.

Turgut, G., \& Kışla, T. (2015). The use of computer-aided story in education: Literature review. Turkish Online Journal of Qualitative Inquiry, April 2015, 6(2), 97-121. https://doi.org/10.17569/tojqi.57305

Ülgen, G. (2001). Concept development: theories and applications. Ankara: PegemA Press.

Van Melle, E., Cimellaro, L., \& Shulha, L. (2003). A dynamic framework to guide the implementation and evaluation of educational technologies. Education and Information Technologies, 8(3), 267-285.

https://doi.org/10.1023/A:1026312110143

Wang, T., \& Andre, T. (1991). Conceptual change text versus traditional text and application questions versus no 
questions in learning about electricity. Contemporary educational psychology, 16(2), 103-116. https://doi.org/10.1016/0361-476X(91)90031-F

Yang, Y. T. C., \& Wu, W. C. I. (2012). Digital storytelling for enhancing student academic achievement, critical thinking, and learning motivation: A year-long experimental study. Computers \& Education, 59(2), 339-352. https://doi.org/10.1016/j.compedu.2011.12.012

Yazıc1, H., \& Samanc1, O. (2003). Levels of Understanding Some Concepts Related to Social Studies Course Subjects of Primary School Students, Journal of Milli Ĕgitim, 158.

Yurdakul, I. K. (2011). Examining technopedagogical knowledge competencies of preservice teachers based on ICT usage. Hacettepe University Journal of Education, 40(40).

\section{Copyrights}

Copyright for this article is retained by the author(s), with first publication rights granted to the journal.

This is an open-access article distributed under the terms and conditions of the Creative Commons Attribution license which permits unrestricted use, distribution, and reproduction in any medium, provided the original work is properly cited. 